\title{
Dokter Beriklan: Sebuah Tinjauan Menurut Kode Etik Kedokteran Indonesia (KODEKI) Tahun 2012
}

\author{
Pukovisa Prawiroharjo ${ }^{\mathrm{r}, 2}$, Putri Dianita Ika Meilia ${ }^{1,3}$ \\ ${ }^{\top}$ Majelis Kehormatan Etik Kedokteran Pengurus Besar Ikatan Dokter Indonesia \\ ${ }_{2}^{2}$ Departemen Neurologi, Fakultas Kedokteran Universitas Indonesia/Rumah Sakit Cipto Mangunkusumo, Jakarta \\ ${ }^{3}$ Instalasi Kedokteran Forensik dan Pemulasaraan Jenazah, Rumah Sakit Umum Pusat Persahabatan, Jakarta
}

\author{
Kata Kunci \\ dokter; etik; etikolegal; iklan produk kese- \\ hatan; kodeki \\ Korespondensi \\ pukovisa@ui.ac.id \\ contact@ilmiah.id \\ Publikasi \\ (C) $2017 \mathrm{JEKI} /$ ilmiah.id \\ DOI \\ I0.26880/jeki.viir.4 \\ Tanggal masuk: 6 Juli 2017 \\ Tanggal ditelaah: 25 Juli 2017

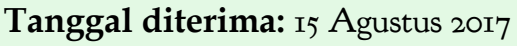 \\ Tanggal publikasi: II Oktober 2017
}

\begin{abstract}
Abstrak Kebutuhan masyarakat akan informasi kompetensi kedokteran di era di mana perkembangan pemasaran dapat dikemas secara eksplisit maupun implisit, baik di media cetak maupun elektronik, menjadi polemik tersendiri bagi dokter. Untuk menunjukkan kapabilitasnya di hadapan masyarakat, penampilan citra baik paling singkat dapat dilakukan melalui iklan. Penelusuran literatur dilakukan untuk menjawab pertanyaan etik terhadap dokter beriklan. Secara etik, baik iklan diri maupun produk dengan klaim kesehatan dan kecantikan yang melibatkan identitas dan gelar seorang dokter tidak dibenarkan kecuali dokter tersebut memiliki STR non-aktif dan/atau pada iklan produk non-kesehatan non-kecantikan yang tidak memunculkan gelar dan atribut dokter sama sekali pada kontennya. Lebih lanjut terkait pelaksanaannya, diharapkan Majelis Kehormatan Etik Kedokteran (MKEK) mampu mengembangkan regulasi baru untuk menindaklanjuti sejawat yang mengalami dilema etik terkait dokter beriklan ini.
\end{abstract}

\begin{abstract}
People's need for medical competency information in an era when marketing may be expressed explicitly or implicitly, both in print and electronic media, has become a polemic for doctors. To publicly announce one's capability, the simplest way would be through advertisements. A literature search was conducted to answer ethical questions of advertising doctors. Ethically, both self-advertisements and health/beauty products associated with identity and title of a physician are not justified unless the physician has non-active license and/or the product advertisement is a non-health, non-beauty, and does not involve the title and attributes of the physician. Further in the implementation, it is expected that the Medical Ethics Council of Honor is able to formulate new regulations to help colleagues who experience ethical dilemmas related to advertising doctor.
\end{abstract}

\section{PENDAHULUAN}

Iklan dalam Kamus Besar Bahasa Indonesia didefinisikan sebagai suatu berita pesanan untuk mendorong dan/atau membujuk khalayak ramai agar tertarik pada barang dan jasa yang ditawarkan. ${ }^{1}$ Selain bersifat sebagai pemberi informasi terhadap produk yang ditawarkan dan sebagai pembujuk calon konsumen untuk melakukan pembelian, suatu iklan juga dapat bersifat sebagai pengingat pesona suatu produk bagi konsumennya agar tetap setia terhadap produk tersebut. Iklan kini dapat disebarkan dalam berbagai ragam media, diantaranya media cetak, televisi, radio, dan yang terbaru adalah secara daring (online) melalui situs-situs sosial yang marak digunakan oleh masyarakat.

Terdapat beberapa pendapat yang pro dan kontra terhadap iklan yang melibatkan dokter. Di satu sisi, masyarakat memiliki hak untuk mendapatkan informasi tentang keberadaan dan kompetensi dokter, serta tentang layanan medis yang sahih dengan meng-counter informasi kesehatan yang menyesatkan atau yang belum memiliki landasan berbasis bukti (Evidence-Based Medicine [EBM]) yang kuat. Selain itu, teman sejawat dan fasilitas layanan kesehatan pun memiliki hak untuk mendapatkan informasi tentang peningkatan/pembaharuan kompetensi yang dimiliki oleh sejawatnya. Dalam konteks ini, penyebaran informasi memiliki peran penting apabila dilakukan sesuai dengan aturan dan kaidah etika kedokteran. Di sisi lain, walaupun dokter merupakan penyedia jasa layanan kedokteran, namun tujuan utamanya adalah untuk menolong, dan bukan seperti penyedia jasa jenis lainnya (misalnya, bidang transportasi, komunikasi, dan sebagainya). Oleh karena itu, atmosfer/iklim kerja yang meliputi dunia kedokteran semestinya bukan iklim kompetisi bisnis untuk meraih profit 
sebesar-besarnya (contohnya dengan menonjolkan diri atau menjatuhkan/menjelek-jelekkan saingan.

Di era globalisasi ini, akses daring terhadap berbagai macam informasi dapat begitu mudah dilakukan. Hal inilah yang tak ayal mendorong dunia periklanan sedikit demi sedikit berpindah haluan ke dunia maya. Bentuk iklan daring pun sangat bervariasi mulai dari foto, gambar bergerak, video, testimoni konsumen, dan artikel. Artikel daring yang mengulas suatu produk awalnya muncul pada suatu situs daring (misalnya dalam bentuk blog pribadi) sebagai bentuk dokumentasi pribadi penggunanya yang ingin dibagikan kepada pengguna lainnya. Ulasan atau testimoni tersebut ternyata dinilai sangat membantu masyarakat dalam melakukan pertimbangan pembelian suatu produk mengingat iklan-iklan yang ada tentunya tidak memberikan gambaran kelemahan produk. Melihat begitu besarnya dampak dari setiap ulasan pada artikel daring, banyak unit usaha yang akhirnya melirik blogger dan administrator akun media sosial terkenal untuk melakukan pengulasan atau review berbayar terhadap produknya. Hal ini kemudian berujung pada timbulnya tuntutan bagi calon konsumen untuk jeli dalam membedakan mana ulasan 'asli' dan mana yang 'bayaran'. Akan tetapi, iklan dalam bentuk artikel kini tidak hanya berbentuk ulasan produk. Artikel berita pun menjadi sasaran baru dari bentuk iklan terselubung. Sebagai contoh, seorang politikus dapat meminta dibuatkan artikel mengenai kebaikan yang dilakukannya sebagai bentuk pengiklanan citra diri secara terselubung. Lantas, bila artikel tersebut dipesan oleh seorang dokter, bagaimanakah tinjauan etik atas kasus tersebut? Kemudian, apakah pemberian kartu nama dokter juga dapat dikategorikan sebagai bentuk pengiklanan diri? Bagaimana dengan seorang blogger yang kebetulan juga berprofesi sebagai seorang dokter, atau seorang dokter yang sangat aktif di media sosial, apakah tulisannya yang menceritakan pengalamannya menggunakan suatu produk atau layanan otomatis dapat menimbulkan dilema etik kedokteran?

Diskusi ini akan dibatasi pada hal-hal mengenai keterlibatan dan inisiatif individu dokter yang bersifat pemasaran implisit dan tidak membahas batasan fasilitas layanan kesehatan dan kasus lainnya dalam beriklan.

\section{METODE}

Untuk mengetahui bagaimana regulasi terkait tinjauan etik dalam kasus ini, penelusuran literatur dilakukan untuk membantu analisis masalah berdasarkan data yang ada pada Profil Kesehatan Nasional tahun 2016 yang diakses melalui situs Kementerian Kesehatan RI dan berdasarkan regulasi yang tercatat dalam UU Praktik Kedokteran tahun 2004 dan Kode Etik Kedokteran Indonesia (KODEKI) tahun 2012 oleh Ikatan Dokter Indonesia yang diakses melalui situs Majelis Kehormatan Etik Kedokteran Ikatan Dokter Indonesia (MKEK IDI).

\section{HASIL DAN PEMBAHASAN}

\section{Kebutuhan Masyarakat terhadap Keahlian Dokter dan Fasilitas Kesehatan}

Hingga tahun 2016, tercatat pada database Kementerian Kesehatan RI terdapat 149.048 dokter tersebar di seluruh Indonesia dengan rincian 116.834 dokter umum dan 32.214 dokter spesialis. ${ }^{2}$ Banyaknya jumlah dokter tersebut tersebar tidak merata dan terkonsentrasi pada pusat-pusat kota tertentu. Rata-rata nasional rasio Puskesmas per 30.000 penduduk tergolong cukup rendah, yakni 1,13 dengan Jawa Barat, Jawa Tengah, Jawa Timur, dan Banten sebagai empat propinsi berasio terendah. Sementara, kebutuhan masyarakat akan keahlian serta kelengkapan layanan kesehatan sama besarnya baik di pusat kota maupun daerah. Menurut rekomendasikan dari World Health Organization (WHO) rasio ideal antara dokter dan pasien adalah 1:2.500. Adapun, di Indonesia hingga saat ini rasio dokter pasien masih jauh dari kata ideal. ${ }^{2-4}$ Akibatnya, aroma 'persaingan' dalam memperoleh pasien tanpa disadari muncul, terutama di kota-kota besar, sehingga urgensi atas kepemilikan citra diri yang tinggi pun meningkat. Di sisi lain, adanya reputasi yang baik dan/atau spesifik terhadap kompetensi tertentu kemudian dapat mempermudah teman sejawat dokter dalam merujuk dengan tepat sasaran sesuai kompetensi yang dibutuhkan pasien. Hal ini tentunya akan membawa kebaikan dalam upaya menjaga kesehatan pasien.

\section{Dilema Etik dari Fenomena Konsumerisme Global}

Fenomena konsumerisme global yang didukung oleh perkembangan daya pikat pemasaran dan periklanan yang kian meningkat pun menjadi salah 
satu faktor yang berperan dalam terciptanya dilema etik ini. Dalam rangka memenuhi kebutuhan akan reputasi, upaya promosi diri dalam bentuk iklan pun bermunculan. Mengandalkan dunia jurnalistik sebagai wadah pembentukan citra, tidak sedikit promosi dengan kedok artikel-artikel 'ilmiah' bertebaran dewasa ini. Selain membentuk citra, meningkatkan popularitas adalah salah satu tujuan lainnya dalam beriklan. Ketenaran ini kemudian dapat ditempuh secara singkat melalui artikel yang menyebar secara viral di dunia maya.

Selanjutnya, beriringan dengan meningkatnya kesohoran seorang dokter, berbagai tawaran untuk menjadi duta merek, bintang iklan, presenter acara, dan profesi lainnya di dunia hiburan pun berdatangan. Dapatkita jumpai di televisi baikstasiun televisi di dalam maupun luar negeri, banyak dokter yang kemudian memberikan testimoni klinis atas suatu produk atau menjadi bintang iklan maupun duta merek dari berbagai produk dengan klaim kesehatan dan kecantikan. Keberadaan seorang dokter dalam iklan suatu produk sering diartikan sebagai keberpihakan dokter tersebut atas produk kesehatan dan kecantikan terkait. Hal ini kemudian dapat menggiring sebuah opini dalam masyarakat bahwa produk tersebut 'direkomendasikan' oleh dokter karena telah 'terbukti manfaatnya secara klinis'. Padahal, di balik layar dokter tersebut tidaklah berperan dalam memutuskan kombinasi komposisi maupun melakukan pembuktian manfaat klinis atas produk tersebut. Adanya potensi timbulnya kesalahpahaman masyarakat kemudian mengundang sebuah kaji etik, di mana dokter dalam kasus ini seolah memberikan rekomendasi produk kepada pasien yang mana dapat mencederai pasien dan/atau bersifat penipuan publik karena rekomendasi yang diberikan bukanlah semata-mata demi kebaikan pasien melainkan untuk keuntungan bisnis.

\section{Tinjauan Etik}

Sejatinya, hal ini telah diatur dalam KODEKI tahun 2012 dalam pasal 3 tentang kemandirian profesi pada cakupan pasal butir (2) poin c yang menyatakan bahwa setiap dokter dilarang melakukan perbuatan "...yang mengakibatkan hilangnya kebebasan dan kemandirian profesi," ${ }^{5}$ yang salah satunya adalah dengan melibatkan diri, baik secara langsung maupun tidak langsung, dalam segala bentuk kegiatan yang bertujuan untuk mempromosikan atau mengiklankan dirinya, barang, dan/atau jasa guna kepentingan dan keuntungan pribadinya, sejawat, maupun pihak lain kelompoknya.

Larangan pengiklanan ini ditegaskan kembali dalam KODEKI tahun 2012 pasal 4 tentang memuji diri yang berbunyi bahwa "Setiap dokter wajib menghindarkan diri dari perbuatan yang bersifat memuji diri." ${ }^{5}$ Setiap dokter wajib mempertahankan profesionalisme dalam menginformasikan kualitas kompetensi dan kewenangan diri kepada sejawat profesi kesehatan dan/atau kepada publik. Dokter wajib menjamin bahwa setiap informasi yang disampaikan bersifat faktual dan terhindar dari segala niat dan upaya untuk menunjukkan kehebatan diri atau memuji diri melalui wahana/ media publik, seperti pertemuan dengan khalayak, media massa, media elektronik, dan media komunikasi berteknologi canggih lainnya. Tindakan yang tergolong ke dalam kegiatan memuji diri adalah mengiklankan kemampuan/kelebihankelebihan yang dimiliki seorang dokter baik secara lisan maupun tulisan, dalam berbagai wahana/ media publik dalam dan luar negeri. Hal ini dapat berupa tulisan yang mengandung pernyataan superlatif, yang antara lain menyiratkan pengertian "satu-satunya ahli" atau makna yang serupa dengan pernyataan keunggulan, keunikan, atau kecanggihan pelayanan pribadi yang cenderung menyesatkan dan bersifat pamer, sehingga dapat menimbulkan kesan yang keliru terhadap profesi.

Oleh karena itu, bila ditemukan keberadaan artikel yang memuat nama seorang dokter dengan konten yang bersifat memuji-muji dokter, dokter yang bersangkutan harus segera mengajukan surat keberatan terhadap konten artikel tersebut karena isinya yang bersifat kurang etis. Contoh lainnya adalah pembagian selebaran dan/atau kartu nama yang mengandung informasi yang bersifat komersial. Bila merujuk pada KODEKI, kartu nama yang dibenarkan secara etik hanyalah kartu nama dengan konten terbatas pada identitas tanpa adanya muatan superlatif maupun komersial. ${ }^{5}$

\section{Hal-hal yang Dianggap Tidak Melanggar Etik}

Larangan beriklan kemudian dapat dikecualikan pada kasus-kasus dimana dokter yang bersangkutan tidak memiliki STR yang aktif (tidak berpraktik sebagai dokter) atau produk yang diiklankan tersebut tidak memiliki klaim kesehatan/kebugaran/ 
kecantikan, dengan catatan dalam kontennya tidak memunculkan gelar maupun atribut kedokteran sama sekali. Tidak diperbolehkannya penggunaan gelar maupun atribut kedokteran dikarenakan oleh keadaan masyarakat yang kurang memahami perihal aktif tidaknya STR dokter sehingga hal ini diharapkan dapat membantu masyarakat dalam membedakan dokter dengan STR aktif dan STR tidak aktif.

Adapun pemasangan iklan pada media cetak dalam rangka pengenalan awal praktik, pengumuman cuti praktik, dan pengumuman kembali buka praktik pasca cuti diperbolehkan dengan ketentuan besar iklan yang dimuat berukuran maksimum 2 kolom x $10 \mathrm{~cm}$ dan hanya berisi informasi nama, jenis spesialisasi, alamat, waktu praktik, nomor telepon (seperti ketentuan papan nama praktek) dengan nomor surat ijin praktik lengkap, tanpa disertai properti persuasif apapun maupun alasan cuti praktiknya tersebut. ${ }^{5}$

Sementara itu, dalam UU Praktik Kedokteran tahun 2004 pasal 41 disebutkan bahwa dokter yang telah mempunyai surat izin praktik dan menyelenggarakan praktik kedokteran wajib memasang papan nama praktik kedokteran pada lokasi praktik. ${ }^{6}$ Untuk itu, dalam KODEKI tahun 2012 juga dicantumkan bahwa pemasangan plang nama dokter pada lokasi praktik tidak digolongkan dalam tindakan beriklan apabila memenuhi ketentuan yang telah ditetapkan. Ketentuan tentang pemasangan plang nama tersebut kemudian diatur dalam pasal 4, cakupan pasal butir (2), yakni plang maksimal berukuran $60 \mathrm{~cm}$ x $90 \mathrm{~cm}$ dengan latar belakang putih dan warna huruf hitam. Dalam plang hanya memuat nama, jenis spesialisasi, nomor surat izin praktik, waktu praktik, dan nomor rekomendasi IDI. Dengan penerangan yang wajar, plang dipasang pada dinding bangunan di depan tempat praktik atau di tepi jalan bagi praktik perorangan, dan di depan/dinding lorong masuk ruang praktik pada rumah sakit, puskesmas, klinik bersama, maupun kantor kesehatan. ${ }^{5}$

Termasuk dalam hal yang diperbolehkan dalam beriklan adalah pengiklanan melalui fasilitas layanan kesehatan, misalnya rumah sakit dan/ atau klinik. Batasan beriklan dari fasilitas layanan kesehatan secara umum diatur secara tersendiri dan lebih fleksibel sebagaimana yang diatur dalam Peraturan Menteri Kesehatan (Permenkes) no. 1787/MENKES/PER/XII/2010. ${ }^{7}$ Hanya saja, pengiklanan fasilitas pelayanan kesehatan sangat perlu memperhatikan pembahasan mengenai batasan dokter beriklan seperti di atas, terutama jika iklan yang direncanakan memuat figur dokter sebagai bagian dari kontennya.

\section{KESIMPULAN}

Adanya perubahan fokus utama dari sekadar memberikan informasi demi kebaikan pasien kemudian bergeser menjadi kepentingan komersial demi memikat 'pelanggan' menjadikan aktivitas periklanan tersebut mencederai hakikat profesi dokter yang seharusnya melakukan segala sesuatu semata-mata demi kebaikan pasien. Tujuan keterlibatan seorang dokter sebagai dokter dalam iklan hanya dibenarkan untuk tujuan memberikan informasi yang dapat dipertanggungjawabkan secara EBM dan keprofesian, misalnya dalam iklan layanan masyarakat terkait program kesehatan tertentu. Di sisi lain, tindakan memuji diri atau bersifat mempromosikan produk atau layanan komersial oleh dokter adalah hal yang berpotensi merendahkan marwah profesi kedokteran. Oleh karena itu, segala bentuk periklanan diri seorang dokter dan periklanan produk dengan klaim kesehatan dan kecantikan yang melibatkan dokter di dalamnya secara etik tidak dibenarkan berdasarkan KODEKI tahun 2012. Lebih lanjut lagi, diharapkan MKEK mampu mengembangkan sebuah regulasi baru maupun fatwa untuk menindaklanjuti sejawat yang tersangkut dilema etikolegal ini.

\section{KONFLIK KEPENTINGAN}

Tidak ada konflik kepentingan.

\section{REFERENSI}

1. Badan Pengembangan dan Pembinaan Bahasa Kementerian Pendidikan dan Kebudayaan Republik Indonesia. Kamus besar Bahasa Indonesia [Internet]. 2016 [disitasi 2017 Jul 4]. Diunduh dari: http://kbbi.web.id

2. Kementerian Kesehatan Republik Indonesia. Profil kesehatan Indonesia 2016. 2017. Diunduh dari: http://www.pusdatin.kemkes.go.id/download. php?file=download/pusdatin/lain-lain/Data-danInformasi-Kesehatan-Profil-Kesehatan-Indonesia2016-smaller-size-web.pdf 
3. Global Health Observatory. Density of physicians (total number per 1000 population, latest available year) [Internet]. World Health Organization. 2017 [disitasi 2017 Aug 22]. Diunduh dari: http://www.who.int/gho/health_workforce/ physicians_density/en/

4. Pusat Komunikasi Publik Sekretariat Jenderal Kementerian Kesehatan Republik Indonesia. Peran jumlah dan mutu tenaga kesehatan dukung percepatan MDGS dan implementasi JKN [Internet]. 2014 Mar 24 [disitasi 2017 Jul 5]. Diunduh dari: http://www.depkes. go.id/article/print/20143250004/peran-jumlahdan-mutu-tenaga-kesehatan-dukung-percepatanmdgs-dan-implementasi-jkn.html

5. Majelis Kehormatan Etik Kedokteran Indonesia. Kode etik kedokteran tahun 2012. Jakarta; 2012.

6. Undang-Undang Republik Indonesia nomor 29 tahun 2004 tentang praktik kedokteran. 2004.

Diunduh dari: http://www.idionline.org/wpcontent/uploads/2010/03/UU-No.-29-Th-2004-ttgPraktik-Kedokteran.pdf

7. Peraturan Menteri Kesehatan Republik Indonesia nomor 1787/MENKES/PER/ XII/2010 tentang iklan dan publikasi pelayanan kesehatan. 2010. Diunduh dari: http://peraturan. go.id/permen/kemenskes-nomor-1787-menkesper-xii-2010-tahun-2010-11e44c50c881c330a5 dd313233303537.html 